\title{
NEKA RAZMATRANJA O UREĐENJU ORGANIZACIJE ZAŠTITE OD POŽARA U RIMSKOM PRAVU
}

U radu su izložene opće odrednice zaštite od požara na temelju sačuvanih tekstova unutar titula De officio praefecti vigilum, pri čemu su detaljnije analizirane dvije povijesne etape i pitanja u vezi s pravnom regulacijom organizacije protupožarne zaštite u rimskom pravu. Nakon uvoda raščlanjen je problem identiteta triumviri nocturni u okvirima republikanskog ustroja magistratura. Zatim se obrađuju pitanja u vezi s obvezama i ovlasti praefectus vigilum i vigiles kao novog oblika organizacije vatrogasne službe u Rimu. Na kraju se iznosi rekapitulacija obrađene materije i zaključci o obrađenim pitanjima pravne regulacije borbe protiv požara u rimskom pravu.

Ključne riječi: požar, službe za zaštitu od požara, borba protiv požara, triumviri nocturni, praefectus vigilum, vigiles.

\section{UVOD}

Požari su zauzimali bitno mjesto u rimskoj povijesti pa su tako šire poznati provala i palež Cala 390. g. pr. Kr. ili Neronov veliki požar iz 66. g., uz koje se u djelima rimskih povjesničara ističu i događaji kada su izgorjele poznate javne građevine poput Jupitrova hrama (83. g. pr. Kr.) ili zgrade Senata (52. g. pr. Kr.). ${ }^{1}$ Međutim, kako se može iščitati iz izvora, oni su bili redovita pojava u manjim razmjerima u kojima su bili uništeni jedan ili više blokova ili dio četvrti. ${ }^{2}$ Štoviše, građevni red jednim je dijelom bio organiziran upravo radi suzbijanja širenja vatre. ${ }^{3}$ Stoga ne iznenađuje da se opasnost od vatre i izbijanja požara (incendium) javlja i u rimskim pravnim izvorima u okviru rasprava o nizu različitih instituta. ${ }^{4} U$ najužoj su vezi sa samim požarima $u$

Dr. sc. Tomislav Karlović, izvanredni profesor Pravnog fakulteta Sveučilišta u Zagrebu (Associate Professor, Faculty of Law, University of Zagreb): tkarlovi@pravo.hr

ORCID ID: orcid.org/0000-0003-1846-1318

1 Primjerice vidi Canter 1932, 270 i sl.

2 Opširnije vidi u: Canter 1932, 273 i sl.; Robinson 1977, 377 i sl.; Sablayrolles 1996, 410 i sl. (uz detaljan pregled literaturnih izvora i statističke podatke o raširenosti požara u određenim dijelovima grada).

3 Primjerice usp. Romac 1975, 141 i sl.; Minieri 2004, 84 i sl.

4 Osnovne naznake različitih instituta koji se izravno odnose na prevenciju i sankcioniranje podmetanja požara i drugih djela u vezi s požarom vidi u: Kleinfeller 1918, 1244 i sl.; Robinson 1977, 377 i sl.; 
Digestama titul D. 1, 15 De officio praefecti vigilum te niz od nekoliko titula 48. knjige u kojima je podmetanje požara određeno kao jedno od sredstava pobune (D. 48, 6) ili počinjenja ubojstva (D. 48, 8), ili je posebno sankcionirano iskorištavanje okolnosti požara i drugih pogibelji za stjecanje imovinske koristi, u prvom redu krađom (D. 48, 7). Uz to, pitanja odgovornosti za podmetanje i štete od požara zauzimaju važnije mjesto u okviru rasprava o primjeni lex Aquilia de damno, pri čemu je dio teksta D. 9 , 2, 27 (Ulpianus libro 18 ad edictum) prenesen i kao dio posebnog titula De incendariis u okviru Collatio legum Romanorum et Mosaicarum. ${ }^{5}$ Iz navedenoga je moguće vidjeti da je riječ o raznorodnoj materiji te širim kompleksima u kojima se javlja niz spornih točaka, pri čemu bismo se ovdje koncentrirali na dva pitanja koja smo uočili pri obradi drugog problema - o posljedicama požara kod ugovora o zakupu, a odnose se na temeljne odrednice pravne regulacije zaštite od požara u rimskom pravu. ${ }^{6}$

Pitanja su u vezi s konkretnom formom i podjelom nadležnosti u okviru organizirane borbe protiv požara. Naime, komentar klasičnog pravnika Paula sačuvan u Digestama prenosi informaciju da je u Rimu vrlo rano počela organizacija posebne službe čiji je osnovni zadatak bio prevencija i zaštita od širenja požara, no, s obzirom na vrlo sumarnu opasku, ona je predmet različitih interpretacija. Također, što se tiče nadležnosti samog praefectus vigilum, koja je predmet obrade u navedenom fragmentu i nekoliko pratećih, iako se na prvi pogled čini da je riječ o jednostavnu i jednoglasno objašnjenu pitanju, u literaturi se susreću divergentni stavovi. Oba pitanja zadiru u temelje prikaza i pojašnjenja različitih aspekata pravne regulacije zaštite od požara te smo im odlučili posvetiti zasebnu pozornost.

\section{PRVOTNA ORCANIZACIJA ZAŠTITE OD POŽARA I SUZBIJANJA POŽARA- TRIUMVIRI NOCTURNI}

Uz određene naznake $u$ literaturnim izvorima, osnovni podatci o državno organiziranoj zaštiti od požara u Rimu preneseni su u relativno kratkom titulu D. 1, 15 De officio praefecti vigilum. Uvodni od pet fragmenata navedenog titula pritom sadržava lapidaran pregled povijesnog razvoja koji je kulminirao uvođenjem posebne službe praefectus vigilum i vigiles kao organizirane vatrogasne postrojbe, dok se u ostalima raspravlja o nadležnosti i ovlastima praefectus vigilum.

\footnotetext{
Robinson 1994, 90 i sl.; Sablayrolles 1996, 5 i sl.; Minieri 2004, 83 i sl. Također, vidi s uputom na daljnju literaturu MacCormack 1972, 382 i sl.; Sitek 2007. Za pojam incendium, odnosno -cando, 2. vidi Ernout $i$ Meillet 1959/2001, 92; Divković 1900/2006, 508 i sl.

5 Vidi s uputom na daljnju literaturu Fercia 2008, 72 i sl; Minieri 2011, 252 i sl. Također, unutar navedenog titula sadržani su i dijelovi Paulovih Sentencija, V, 20, za čiji tekst vidi Romac 1989, 224 i sl.

6 Vidi Karlović 2021.
} 
Slijed službi koje su bile zadužene za borbu protiv požara iznosi Paulo u tekstu D. 1, 15, 1:

D. 1, 15, 1 (Paulus libro singulari de officio praefecti vigilum) Apud vetustiores incendiis arcendis triumviri praeerant, qui ab eo, quod excubias agebant nocturni dicti sunt: interveniebant nonnumquam et aediles et tribuni plebis. Erant autem familia publica circa portam et muros disposita, unde si opus esset evocabatur: fuerant et privatae familiae, quae incendia vel mercede vel gratia extinguerent, deinde divus Augustus maluit per se huic rei consuli.7

Navodi se tako da je u staro doba ustanovljena posebna magistratura - tresviri (ili triumviri) ${ }^{8}$ koji su bili zaduženi za borbu protiv požara i paljevina, a koji su s obzirom na djelovanje noću nazvani i triumviri nocturni. ${ }^{9}$ Također, uz njih su djelovali i edili i plebejski tribuni, a općenito su svima na raspolaganju za borbu protiv vatre bili javni robovi raspoređeni oko ulaza u grad i na zidinama. Konačno, što potvrđuju i literaturni izvori' ${ }^{10}$, i privatne su osobe organizirale vlastite robove koji su bili spremni pomoći u gašenju požara, besplatno ili uz naplatu. Na kraju, kako Paulo dodaje, vatrogasnu službu na profesionalnim temeljima ustrojio je August, pri čemu se opis ovlasti te nove službe nastavlja u trećem fragmentu nakon ubačenoga Ulpijanova komentara koji bi objasnio razlog osnivanja nove službe - istodobna pojava većeg broja požara za čije gašenje postojeća organizacija očito nije bila zadovoljavajuća."1 Navedeni požari mogli bi se povezati s izvještajima Kasija Diona, LV, 8, 6, o požaru koji je zahvatio veći broj zgrada oko Foruma 7. g. pr. Kr. kada je August napravio prvu reformu protupožarne zaštite, prebacujući je iz ruku edila u one novoimenovanih vicorum magistri, što je poslije pratilo uvođenje vigiles. ${ }^{12}$

Općenito Paulovo apud veteres otvara širi prostor za određenje vremena uvođenja i djelovanja triumviri nocturni. Na temelju dijelova Livijevih zapisa prva naznaka njihova postojanja bila bi u IX, 46, 3, u kojem se pozivom na Licinija Macera navodi da jeCnej Flavije prije ediliteta 304. g. pr. Kr. obavljao funkciju triumvir nocturnus. ${ }^{13}$ Međutim, u literatu-

7 D. 1, 15, 1: „Kod predaka su za zaštitu od požara i paljevina bili zaduženi triumviri koji su zbog toga što su obavljali straže noću nazvani nocturni. Ponekad su intervenirali i edili i plebejski tribuni. Bila je uz to raspoređena i skupina javnih robova oko ulaza u grad i zidova koji bi bili pozvani u slučaju potrebe, a bile su i privatne skupine robova koje su gasile požare uz naknadu ili besplatno. Na kraju je božanski August odlučio sam riješiti ovu stvar." Usp. Lenel 1889, 1144.

8 S obzirom na to da se u izvorima i literaturi upotrebljavaju oba pojma, i tresviri i triumviri, u radu će oni ponajprije slijediti izvore i djela koji će biti predmet izlaganja, dok će samostalno biti preferiran termin triumviri prema Paulovu tekstu kao polazišnoj točki razmatranja.

9 Usp. Mommsen 1874, 580 i sl.; MacCormack 1972, 384 i sl.; Robinson 1977, 378 i sl.; Sablayrolles 1996, 12 i

sl.; Cascione 1999, 9 i sl.; Kołodko 2012, 199 i sl.

10 Vidi, primjerice, navode u Robinson 1977, 378 i sl.

"D. 1, 15, 2 (Ulpianus libro singulari de officio praefecti vigilum): „Pluribus uno die incendiis exortis:“" (Jer je više požara izbilo u jednom danu.). Usp. Lenel (II) 1889, 960.

12 Sablayrolles 1996, 25 isl.

13 Liv., IX, 46, 1-3: „1. Eodem anno Cn. Flavius Cn. filius scriba, patre libertino humili fortuna ortus, ceterum callidus vir et facundus, aedilis curulis fuit. 2 . Invenio in quibusdam annalibus, cum appareret aedilibus fierique se 
ri se češće prema Per. XI, $8^{14}$, a u vezi s Liv. XXXIX, 14,10 u kojem se opisuju ovlasti tresviri capitales, među kojima su nadzor noćnih okupljanja i straža da ne dođe do požara, te se navodi da su njihovi pomoćnici bili quinqueviri uls cis Tiberim ${ }^{15}$, uzima da je magistratura osnovana između 290. i 287. g. pr. Kr. ${ }^{16}$ Naime, glavni je problem datiranja pitanje odnose li se termini triumviri capitales i triumviri nocturni na istu magistraturu, konkretnije na općenitije poznate triumviri capitales, ili je riječ o dvjema zasebnim službama. ${ }^{17}$

Mommsen je, stavljajući pod sumnju kao nepouzdane navode Licinija Macera, ustvrdio da je riječ o istim magistraturama ${ }^{18}$, a navedeni stav prihvaćaju i autori poput MacCormacka ${ }^{19}$ i Robinson ${ }^{20}$, te je on preuzet i kod većine kasnijih autora. ${ }^{21} \mathrm{~S}$ druge strane, može se istaknuti Langeovo tumačenje različitih naziva u smisle transformacije iz jednog u drugi oblik ${ }^{22}$, odnosno da su triumviri nocturni uvedeni nakon 390 . kao pomoćnici koji su imenovani i djeluju po nalogu viših magistrata, u prvom redu pretora, no da je stalna magistratura uvedena tek poslije u formi triumviri capitales donošenjem lex Papiria. ${ }^{23}$, ${ }^{24}$ Slično je tomu i Strasburgerovo objašnjenje ${ }^{25}$ o proširenju ovlasti i promjeni naziva koje je prihvatio i Kunkel ${ }^{26}$, a istu liniju razmišljanja može

pro tribu aedilem videret neque accipi nomen quia scriptum faceret, tabulam posuisse et iurasse se scriptum non facturum; 3. quem aliquanto ante desisse scriptum facere arguit Macer Licinius tribunatu ante gesto triumviratibusque, nocturno altero, altero coloniae deducendae." (1. Iste godine pisar Cn. Flavije, sin Cnejev, od oca oslobođenika nižeg podrijetla, ali mudar i elokventan, bio je pisar. 2. Pronalazim u nekima od anala (povijesnih kronika) da je pomagao edilima te da se pobrinuo da bude izabran od jednog tribusa za edila, no kako izbor nije priznat jer je bio pisar, sastavio je ispravu i zakleo se da to više neće činiti; 3. što je već i prije prestao činiti, kako je argumentirao Licinije Macer, obavljajući prije tribunata funkcije triumvira, jedne godine noćne straže (nocturnus), druge za osnivanje kolonije (deducendae coloniae).)

${ }_{14}$ Per. XI, 8: „Triumviri capitales tunc primum creati sunt." (Tada su prvi put stvoreni triumviri capitales.).

15 Liv., XXXIX, 4, 10: „Triumuiris capitalibus mandatum est ut uigilias disponerent per urbem seruarentque ne qui noctumi coetus fierent utque ab incendiis caueretur; adiutores triumuiris quinqueuiri uls cis Tiberini suae quisque regionis praeessent." (Naređeno je triumviri capitales da rasporede noćne straže po gradu i da paze da se nitko ne skuplja po noći te da osiguraju da ne dođe do požara; pomoćnici triumviri bili su za svoje regije quinqueviri za ovu i onu stranu Tibera.).

16 Osnovno vidi Mommsen 1874, 558; Cascione 1999, str. 6.

17 Za popis autora i djela do kraja 19. stoljeća koji zastupaju obje teze usp. Cascione 1999, 9, bilj. 18.

18 Usp. Mommsen 1874, 558.

19 U vezi s tresviri nocturni utvrđuje: „These are apparently the same as the tresviri capitales instituted between the years 290 and 287 B.C."Usp. MacCormack 1972, 384.

${ }_{20}$ "The tresviri nocturni, mentioned by Paul, (to be identified with the tresviri capitales, but mentioned on the less common form by Livy in 304 B.C.)...". Usp. Robinson 1977, 379.

${ }_{21}$ Usp. Nippel 1995, 22 i sl.; Licandro 1999, 184; Lintott 1999, 104; Sitek 2007, cap. 4; Kołodko 2012, 200 i sl.; Fuhrmann 2016, 299. Iz domaće literature usp. Horvat 1943, str. 58; Jaramaz-Reskušić 2003, 83, bilj. 275.

22 Vidi Lange 1856, 651.

${ }^{23}$ Opširnije vidi u La Rosa 1957, 231 i sl.; Cascione 1999, 21 i sl.

${ }_{24}$ Na uvođenje navedenim zakonom, a na inicijativu plebejskog tribuna Lucija Papirija kojim je predviđen izbor tres viri u skupštini, upućuje Fest. s.v. Sacramentum (468 L.). U vezi s Festovim tekstom opširnije, s uputom na daljnju literaturu, vidi Petrak 2006, 1271 i sl.

25 Vidi Strasburger 1939, 518.

26 Kunkel i Wittmann 1995, 533, bilj. 3. 
se prepoznati i kod Petruccija. ${ }^{27}$ Izravno se na Langea referira Cascione, pri čemu se njegova kronologija razvoja razlikuje u tome što je prema Langeu stalna magistratura uvedena 290. g. pr. Kr., na temelju Per. XI, 8, dok bi prema Cascioneu to bilo između 242. i123. g. pr. Kr. ${ }^{28}$ Cascione se pritom oslanja na već iznesene teze ${ }^{29}$, no stavlja naglasak na Pomponijev redoslijed izlaganja događaja u D. 1, 2, 2 i paragraf D. 1, 2, 2, 31 (Pomponius libro singulari enchiridii) ${ }^{30}$ u kojem se spominju quinqueviri kao pomoćnici tresviri kao kod Livija, XXXIX, 14, 10, a koji se tumači u smislu da bi za tresviri bilo neodgovarajuće da idu u noćne ophodnje nakon uzdizanja na razinu stalne magistrature. ${ }^{31}$ Kako je navedeni paragraf slijedio nakon D. 1, 2, 2, 28 u kojem se spominje uvođenje praetor peregrinus ${ }^{32}$, terminus post quem bila bi 242. g. pr. Kr., dok je terminus ante quem određen prema lex Acilia repetundarum i lex Latina Tabulae Bantinae u kojima se spominju Illviri capitales. ${ }^{33}$ Konkretnije, a u vezi s Plautovom komedijom Truculentus (Truc. 4.2.47 = 758), Cascione smatra da je lex Papiria donesena u prvim desetljećima 2. st. pr. Kr. ${ }^{34}$

Sablayrolles iznosi zasebno, drukčije shvaćanje relevantnih izvora..$^{35}$ Temelj za odbacivanje Momsennova tumačenja nalazi u Paulovu spominjanju triumviri nocturni, što smatra da bi bilo začuđujuće da je magistratura prije, još tijekom 3. st. pr. Kr., apsorbirana od triumviri capitales. Činjenicu da Livije spominje triumviri nocturni za 304. g. pr. Kr., a Valerije Maksim za $241 .{ }^{36}$ i 211. g. pr. Kr. ${ }^{37}$, dok se 186. g. pr. Kr. kod Livija

27 Autor tako govoreći o tresviri capitales navodi: „Le origini dei tresviri si fanno risalire ai triumviri notturni (triumviri nocturni), che vediamo comparire verso la fine del IV secolo a.C., in qualità di collegio non stabile, cui affidare, in caso di necessità, la prevenzione degli incendi ed un'embrionale funzione di controllo dell'ordine pubblico nelle ore notturne." Usp. Petrucci 2012, 284.

${ }_{28}$ Usp. Lange 1856, 651; Cascione 1999, 24. Također usp. Kunkel 1962, 71.

29 Vidi tako kod Mommsena da je lex Papiria izglasana između 512. i 630. a.U.c., a prema Festovu navođenju dva pretora te spomenu magistrature u zakonima iz cca. 123. g. pr. Kr. Usp. Mommsen 1874, 558, bilj. 6. 30 D. 1, 2, 2, 31 (Pomponius libro singulari enchiridii): „Et quia magistratibus vespertinis temporibus in publicum esse inconveniens erat, quinqueviri constituti sunt cis Tiberim et ultis Tiberim, qui possint pro magistratibus fungi." (I zbog toga što je magistratima bilo nezgodno biti u javnosti u večernjim satima ustanovljeni su quinqueviri s ove i one strane Tibera koji bi mogli djelovati umjesto magistrata.). Usp. Lenel (II) 1889, 48.

31 Vidi Cascione 1999, 24.

32 Za uvođenje usp. Horvat 1943, 53.

33 Vidi Cascione 1999, 28; Romano 2016, 97 i sl. Usp. Johnson et al. 1961/2009, 18 (doc. 11), 59 (doc. 55).

${ }_{34}$ Cascione 1999, 33. Contra vidi La Rosa 1957, 232.

35 Vidi Sablayrolles 1996, 12 i sl.

36 Val. Max. 8.1. damn.5: „Possumus et ad illos brevi deverticulo transgredi, quos leves ob causas damnationis incursus abripuit. M. Mulvius, Cn. Lollius, L. Sexitilius triumviri, quod ad incendium in sacra via ortum exstinguendum tardius venerant, a tribunis pl. die dicta apud populum damnati sunt." (Možemo napraviti kratku digresiju i zbog onih koje je zbog lakših razloga stigla osuda. M. Mulvije, Cn. Lolije, L. Sekstilije, triumviri koji su kasno stigli da bi ugasili požar na Via Sacra navedenog su dana osuđeni po plebejskom tribunu ispred naroda.). Usp. Briscoe 2019, 91 i sl.

37 Val. Max. 8.1. damn.6: „Item P. Villius triumvir nocturnus a P. Aquilio tribuno pl. accusatus populi iudicio concidit, quia vigilias neglegentius circumierat." (Isto tako je i triumvirnocturnus P. Vilije optužen od plebejskog tribuna P. Akvilija osuđen (propao) od naroda jer je nemarno obavljao noćnu stražu.).

Vidi komentare te opširnije za tekst u: Licandro 1999, 184 i sl.; Briscoe 2019, 92 i sl. 
u istoj funkciji spominju triumviri capitales, objašnjava konkretnim okolnostima 186. g. pr. Kr. i djelatnostima u vezi sa suzbijanjem bakanalija na razini cijele službene vlasti Rima. Radi osiguranja koordinirana pristupa borbi, a u vezi s prethodnim navodima iz Liv., XXXIX, 14, Sablayrolles smatra da je te godine bila riječo izvanrednom davanju ovlasti koje su inače pripadale triumviri nocturni u ruke triumviri capitales od konzula kao i podređivanju njihovih pomoćnika toj magistraturi. ${ }^{38}$ Nakon smirivanja situacije ponovno bi oživjela stara podjela ovlasti te su triumviri nocturni bili samostalno zaduženi za borbu protiv požara. S obzirom pak na važnost i opsežnost navedenih obveza u vezi sa zaštitom od požara, taj autor kao logički argument u smislu odvojenosti dviju služba ističe i da bi bilo teško očekivati da su triumviri capitales uz policijske poslove, vođenje zatvora i izvršenje presuda imali vremena i za poslove noćne straže i gašenja vatri po gradu. ${ }^{39}$

Općenito što se tiče autorovih zaključaka, kao i drugih iznesenih teorija, teško je izvući siguran zaključak na temelju dostupnih izvora. Izričito triumviri nocturni spominju samo Paulo, Livije i Valerije Maksim, pri čemu Valerije Maksim spominje zaredom prvi put samo triumviri (Val. Max. 8.1. damn. 5), a u sljedećem paragrafu triumvir nocturnus (Val. Max. 8.1. damn. 6). Navedeno bi se moglo tumačiti u smislu istovjetnosti magistratura jer se triumviri capitales koji su zabilježeni puno češće, $i$ to posebno u epigrafskim spomenicima ${ }^{40}$, katkad nazivaju i samo triumviri. Problem je u vezi s potonjima primarno $u$ tome što se $u$ literaturnim izvorima ovlasti triumviri capitales glede požara ističu samo kod Livija, XXXIX, 14, 10. Ako se vratimo na Paulov izričaj i navod nocturni dicti sunt, ako se usporedi redovita uporaba termina u Digestama, to bi moglo upućivati na to da je doista riječ o stvarnom nazivu, a ne samo o kolokvijalnom imenu. Međutim, moguće je da je pri uzimanju u obzir više različitih izvora došlo i do pogreške u tumačenju posredujućih djela, posebno ako se usporedi nesuglasje Paula i Pomponija u vezi s time komu bi pomagali quinqueviri. ${ }^{41}$

Kod Paula može se uočiti da se nocturni navode primarno kao stara ustanova, apud veteres, koja više nije prisutna, odnosno oni bi bili osvjedočeni za godine 304. i 211. pr. Kr., ali ne i za kasnije razdoblje. Početci službe svakako bi pristajali u četvrto stoljeće kada je uvedena i pretura i kurulski edili (367. g. pr. Kr.). ${ }^{42}$ Ako se pak pretpostavi da su nocturni prestali djelovati uvođenjem vigiles, kako bi se moglo zaključiti prema Paulu, pitanje je međutim što je s razdobljem između 211. g. pr. Kr. i Augustova doba i zašto se ne pojavljuju u izvorima. Izostanak bi se mogao interpretirati u svjetlu Cascioneo-

\footnotetext{
${ }_{38}$ Usp. Sablayrolles 1996, 14 i sl.

39 Ibid., str. 15 i sl. Što se tiče ovlasti i obveza triumviri capitales, primjerice, vidi Kunkel 1962, 71 i sl.

40 Usp. Cascione 1999, 208 i sl.

${ }_{41}$ Za Paulove povijesne izvore vidi Maschi 1976, 690, dok za Pomponija usp. Nörr 1976, 518 i sl.

42 Usp. Eisner i Horvat 1948, 33 i sl. Također, moguća poveznica bilo bi osnivanje praefecti Capuam Cumas 318. g. pr. Kr. prema Liv. IX, 20, 5, no navedena je godina sporna (argumenti za razdoblje tek nakon 210. g. pr. Kr.). Usp. Enßlin 1954, 1284.
} 
ve teze prema kojoj bi između 242. i 123. g. pr. Kr., vjerojatno oko 200. -184. g. pr. Kr., došlo do transformacije iz triumviri nocturni u capitales donošenjem lex Papiria, iako bi se s obzirom na prijašnje navode capitales kod Livija to prije moglo tumačiti kao preuzimanje ovlasti. U tom smislu mogao bi se shvatiti i Livijev unos za 186. g. pr. Kr., a koja bi pomaknula Cascioneove granice najkasnijeg vremena donošenja zakona koju godinu i ranije od Plautove smrti.

Značenje Liv. XXXIX, 14, 10 bilo bi to veće zbog navoda quinqueviri, a koji su bili ključni u raspravi o tome jesu li triumviri samostalno patrolirali noću. Naime, ako se uzme da su capitales obavljali službu i straže od požara, postavlja se pitanje, na tragu onoga što s pravom kao prigovor iznosi Sablayrolles, kada su to stigli uza sve obveze u vezi s policijskim poslovima i nadzorom nad pravosuđem koje su imali redovito. Naime, te su dužnosti obuhvaćale i hvatanje robova koji su lutali te njihovo kažnjavanje, stavljanje u zatvor osoba koje su uhvatili na djelu ili po prijavi kao i nadzor nad izvršavanjem kazni i ovrha te drugo. ${ }^{43}$ Pritom navedenu kumulaciju obveza ne treba olako shvatiti jer je nemarno obavljanje protupožarne aktivnosti moglo dovesti i do kapitalnih kazni, na što se upravo odnose bilješke Valerija Maksima o osudama na temelju tužbi plebejskih tribuna zbog zakašnjele reakcije na požare. ${ }^{44} \mathrm{Vjerujemo} \mathrm{da}$ su rješenje navedenog problema upravo bili quinqueviri kao pomoćnici, koje spominju i Paulo i Pomponije, kao i prije Livije, koji bi bili u ophodnjama svaki za svoju regiju ${ }^{45}$, dok su triumviri vjerojatnije bili „u pripravnosti“ te bi izravno intervenirali po potrebi. ${ }^{46}$ Općenito bi se moglo pretpostaviti da bi njihova zadaća nakon uvođenja quinqueviri prije bila osigurati odgovarajuće funkcioniranje nadzora i biti pri ruci kada je trebalo donijeti konkretnu odluku. Inače bi teško bilo zamisliti da bi bili aktivni i cijeli dan i cijelu noć. U tom smislu, a vezano na spominjanje i triumviri capitales i triumviri nocturni tijekom 3. stoljeća te s obzirom na ulogu quinqueviri 186. g. pr. Kr., vjerujemo da je moguće da su upravo quinqueviri zamijenili ranije triumviri nocturni, odnosno da je došlo do povećanja njihova broja. Uz to, quinqueviri kao pomoćnici u ophodnjama ne bi bili vjerojatni uz nocturni koji su sami bili pomoćnici magistrata, već prije uz capitales koji su postali magistratus minores, moguće upravo između 211. i 186. g. pr. Kr., što je blizu i Cascioneova prijedloga.

Što se tiče nestanka ili apsorpcije, odnosno nepostojanja triumviri nocturni tijekom 2. i 1. st. pr. Kr., čini nam se da je još važniji indikator izostanak naznake te funkcije u

${ }_{43}$ Detaljniji pregled vidi u Kunkel 1962, 71 isl.; Cascione 1999, 84 i sl.; Lintott 1999, 102 i sl.; Jaramaz-Reskušić 2003,83 , bilj. 275.

${ }^{44}$ Vidi opširnije u Licandro 1999, 184 i sl.

${ }_{45}$ Za podjelu na pet regija Rima, četiri tradicionalne cis Tiberim i jednu s druge strane Tibera, usp. Pailler 1985, 785 isl.

${ }^{46}$ Primjerice, to se može zaključiti za 63. g. pr. Kr., a u vezi s Katilininom urotom, o čemu je Salustije pisao „...Romae per totam urbem vigiliae haberentur eisque minores magistratus praeessent“" (Sall. Cat. 30, 7). Usp. Lintott 1999, 105. 
epigrafskim spomenicima. ${ }^{47}$ Ako bi magistratura postojala paralelno s triumviri capitales, bilo bi očekivano da je i ona s obzirom na važnost bila dignuta na istu razinu kao i triumviri capitales, u smislu izbora na tributskim skupštinama te da bi bila zabilježena kao dio cursus nekog od rimskih građana, međutim takvi podatci nedostaju. Obavljanje funkcije capitalis višestruko je zabilježeno, a primjerice čak je i Lucius Funisulanus Vettonianus, patron municipija Andautonija, obavljao funkciju IIlvir. ${ }^{48}$ Doduše, Lucije je živio u drugoj polovici 1. stoljeća, no triumviri (capitales) osvjedočeni su i za razdoblje prije uvođenja vigiles. ${ }^{49}$ Što se pak tiče sačuvanih leges municipales kao možebitnih referencija koje reflektiraju uređenje $u$ Rimu ${ }^{50}$, osim navedene Lex Latina Tabulae Bantinae, u njima se ne navode ni triumviri capitales ni nocturni ${ }^{51}$, već je zaštita od požara po potrebi prepuštena u ruke edila, stoga ne pružaju potporu ni u jednom smjeru. ${ }^{52}$

U kontekstu borbe od požara i Paulova teksta o povijesnom razvoju jedan je od elemenata koji bi eventualno mogao biti argument u korist kontinuiteta s triumviri capitales, ili za postojanje triumviri nocturni, i nadležnost, odnosno ovlasti praefectus vigilum. Problem je, međutim, što konkretnije obveze i ovlasti u vezi s borbom protiv požara nisu vidljive osim iz literaturnih izvora, i to samo na općoj razini tko se trebao brinuti za što. To je posebno izraženo u vezi s triumviri, pri čemu se može uočiti iz izvora za Augustovo doba, primjerice Velej Paterkul i Kasije Dionn ${ }^{53}$, da oni u kontekstu borbe protiv požara ne govore ni o jednim triumviri, već su prema njima ključnu ulogu imali edili kao viši magistrati. S obzirom na navedene izvore moglo bi se konstatirati da su Augustove reforme uvedene prije radi nadopune i zamjene starog sustava zaštite od požara u kojem su glavnu ulogu preuzeli edili. ${ }^{54} \mathrm{Iz}$ Paulovih uvodnih riječi može se pak izvući zaključak da je konkurencija više službi, što bi prema redovitu tijeku stvari povlačilo i probleme u koordinaciji napora u obrani od požara, bila jedan od glavnih razloga reformi. Ne ukidajući republikanske magistrature, pa tako ni triumviri capitales koji su i dalje bili jedna od ulaznih pozicija cursus honorum ${ }^{55}$, August je u skladu sopćim pristupom kontroli grada uveo samo novu, paralelnu službu.

\footnotetext{
47 Što se tiče navoda Domaszewskog koji bi se odnosio na 216. g., doista je upitna stvarna referencija na istu magistraturu. Usp. Domaszewski 1892, 160.

48 Prema CIL XI, 571. Usp. Houston 1976, 24 i sl. Općenito za Lucija Funisulana Vettoniana, s uputom na daljnju literaturu, vidi Karlović 2006, 51 i sl. Usp. Cascione 1999, 226 i sl.

49 Usp. Cascione 1999, 208 i sl.

50 Vidi za municipalne magistrature i njihove ovlasti priloge u Capogrossi Colognesi i Cabba 2006.

${ }^{51}$ Što se tiče navoda Illviri u epigrafskim zapisima iz kolonija, kao i opovrgavanja relevantnosti određenih izvora, usp. Cascione 2010, 29 i sl.; Romano 2016, 92 i sl.

${ }_{52}$ Cap. 19 lex Irnitana u vezi s obvezama edila: „vigilias cum res desiderabit exigendi“. Usp. Wolf 2011, 46. Vidi i Roselaar 2016, 127.

$53 \mathrm{U}$ vezi s Egnacijem Rufom i kako je postigao slavu kao edil uspješnom borbom protiv požara vidi Vell. Pat. 2, 91 i Cass. Dio. 53, 24. Usp, Badot 1973, 607 i sl.; Robinson 1977, 378; Sablayrolles 1996, 9, bilj. 10.

${ }_{54}$ Usp. Sablayrolles 1996, 22 i sl.

55 Usp. Eck 2015, 626 i sl.
} 


\section{O OVLASTIMA VIGILES I PRAEFECTUS VICILUM U PROTUPOŽARNO] BORBI}

Za vrijeme Augusta 6. godine došlo je do reorganizacije zaštite od požara i ustanovljenja vigiles, profesionalne vatrogasne jedinice na čelu s praefectus vigilum. ${ }^{56} \mathrm{Kako}$ piše Paulo, D. 1, 15, 3, pr. (Paulus libro singulari de officio praefecti vigilum), ona se sastojala od sedam kohorti na čijem su čelu bili tribuni, a koje su bile zadužene za 14 gradskih područja (regiones), odnosno svaka kohorta za dvije regije. ${ }^{57}$ Njihove su se obveze, kada nisu gasili požare, odnosile na nadzor nad pridržavanjem pravila čija je svrha bila sprečavanje njihova nastanka te osiguranje postojanja zaliha vode i drugih stvari potrebnih za gašenje. Premda Paulo u prvom redu govori o ovlastima i dužnostima praefectus vigilum, ako bi se krenulo od preventivnih aktivnosti službe opisanih $u$ paragrafima 3 i 4, postoje sumnje da se navedeni dijelovi teksta doista odnose ne (samo) na samog prefekta, već općenito na vigiles. ${ }^{58}$ Riječ je o sljedećim dijelovima centralnog teksta tog titula:

D. 1, 15, 3 (Paulus libro singulari de officio praefecti vigilum) 3. Sciendum est autem praefectum vigilum per totam noctem vigilare debere et coerrare calciatum cum hamis et dolabris, ut curam adhibeant omnes inquilinos admonere ${ }^{59}$, ne neglegentia aliqua incendii casus oriatur. 4. Praeterea ut aquam unusquisque inquilinus in cenaculo habeat, iube(n)tur admonere. ${ }^{60}$

Nakon prethodnog opisa nadležnosti i mogućnosti kažnjavanja u slučaju požara ili opasnosti od požara na koje ćemo se vratiti, Paulo navodi da je prefekt morao cijele noći obilaziti grad opremljen za gašenje vatre, uz to upozoravajući stanare da paze na vatre i da imaju određenu količinu vode u stanovima za slučaj izbijanja požara. ${ }^{61}$

56 Vidi opširnije u: Rainbird 1976; Daugherty 1992, 229 i sl.; Robinson 1994, 91 i sl.; Sablayrolles 1996, 24 i sl.; Kołodko 2012, 202 i sl.; Petrucci 2012, 125. U vezi s postklasičnim izmjenama službe usp. En lin 1954, str. 1346; Sablayrolles 1996, str. 61 (posebno da ih nema više 386. g.).

57 Uz to može se dodati da je svaka kohorta imala od 560 do 1.000 ljudi podijeljenih u sedam centurija, pri čemu su ovdje citirani autori bliži nižoj brojci. Sablayrolles se pritom oslanja na prijašnjih 600 robova koje je August dao na raspolaganje edilima za borbu protiv požara 22. g. pr. Kr., broj raspoloživih oslobođenika za službu vigiles te na visinu troškova plaća zbog čega je uveden i poseban porez od 2 \% na prodaju robova. Usp. Rainbird 1976, 150 i sl.; Daugherty 1992, 230; Sablayrolles 1996, 27 i sl.

${ }^{58}$ Vidi Cuarino 1962, 349 i sl.

59 Smatra interpolirano Lenel (Lenel 1918, 123), a Kunkel (Kunkel 1925, 335) i šire do oriatur, no prema Dell'Orovu izričaju može se zaključiti njegov stav o integralnom sadržaju teksta (Dell'Oro 1960, 252). Guarino pak smatra da je sav tekst nakon dolabris, i "ut curam ... oriatur", kao dodatak prvoga postklasičnog autora, i „Praeterea ... admonere." od drugoga glosatora, interpoliran (Guarino 1962, 350). Kod kasnijih autora, prema navodima teksta bez naznake interpolacije ili bez problematiziranja njegova sadržaja, može se uočiti izostanak sumnji na interpolacije.

${ }^{60}$ D. 1, 15, 3: „3. Treba također znati da praefectus vigilum mora cijele noći biti u ophodnji te obilaziti grad prikladno obuven i snabdjeven kantama i sjekirama, upozoravati sve stanare zgrada na dužnu pažnju da zbog nemara ne bi došlo do požara. 4. Prije svega dužan je upozoravati da svaki stanar u svom stanu ima vode (za gašenje požara)." Usp. Lenel (I) 1889, 1144. Vidi Guarino 1962, 349 i sl.

${ }_{61}$ Uz navedeno treba upozoriti i na Ulpijanov tekst D. 33, 7, 12, 16 i 18 (Ulpianus 20 ad Sabinum), u kojem se pozivajući na Pegaza navodi redovit inventar (instrumenta) prisutan u kućama u vezi s gašenjem 
Na temelju Beselerove kritike teksta i uz nju ${ }^{62}$, Guarino je istaknuo da bi se riječi coerrare odnosile na veći broj ljudi koji je išao u skupini zajedno, kao i da bi nelogično bilo navoditi sjekire i kante u množini ako je riječ o jednoj osobi. ${ }^{63}$ Dell'Orovu tvrdnju da se prefekt na taj način prezentirao prema građanima ${ }^{64}$ Cuarino je razumljivo izložio kritici smatrajući to malo vjerojatnim, s čime se može složiti jer bi doista bilo začuđujuće da je uz tribune i mogućih 80 vigiles u jednoj centuriji prefekt sam nosio kante i sjekire. Stoga bismo se i priklonili tumačenju toga dijela teksta u smislu preventivnog djelovanja u sprečavanju nastanka požara samih vigiles tijekom njihovih noćnih ophodnji. ${ }^{65}$ Argument u korist navedenog bio bi i navod iz Petronijeva Satirikona, 78, 7, prema kojem su vigiles „suo iure" provalili u Trimalhionovu kuću misleći da je došlo do požara. ${ }^{66}$ Međutim, upitna je Guarinova tvrdnja da je prefekt noću mirno spavao u kući dok su vigiles bili u ophodnjama, u prvom redu s obzirom na moguće veće intervencije te da su ovlasti kažnjavanja bile dane osobno njemu. Prije bi se moglo i u vezi s njim, kao i prije s triumviri, pretpostaviti da je bio u pripravnosti, ili da je dio večeri provodio u obilasku kohorti. Štoviše, ako bi se i iz izmijenjenog teksta nešto moglo zaključiti, iako to možda nije bilo tako kod Augusta, jest to da bi se prema shvaćanju kasnijeg autora očekivalo da prefekt bude prisutan u ophodnjama. Također, u vezi sa sačuvanom verzijom teksta, ako bi se doslovno tumačilo samo nemarno držanje vatre kao razlog upozorenja ili bičevanja (kao oblik coercitio), prema prvom paragrafu tog fragmenta i Ulpijanovu komentaru sačuvanom u D. 1, 15, 4 (Ulpianus libro singulari de officio praefecti Urbi), može se zamisliti da bi ih naređivao i na licu mjesta.

Naime, Paulo je nakon uvoda o povijesnom razvoju i organizaciji detaljnije obrazložio nadležnost praefectus vigilum u slučaju hvatanja podmetača, izazivača požara:

požara (quod tempestatis arcendae aut incendii causa paratur, odnosno quod exstinguendi incendii causa paratur). Vidi Minieri 2004, 89.

${ }_{62}$ Kritika, prema Guarinu, temeljila se na broju kod glagola adhibeant (iako nije jasno zbog čega ako bi se odnosilo na inquilinos) i iubentur (Mommsen je u izdanju Digesta ispravio u iubetur) te apsurdnosti da uza sve obveze po danu prefekt mora i pod punom opremom ići u ophodnje i noću. Vidi von Beseler 1930, 2 i sl.; Guarino 1962, 348 i sl.

63 Cuarino 1962, 349.

${ }^{64}$ Dell'Oro 1960, 252, bilj. 549: „Il prefectus vigilum deve cioè presentarsi in tenuta di servizio per poter essere subito riconosciuto ed esercitare prontamente la sua autorità." $U$ tom smislu i du Plessis govori „Thus, in the city of Rome, the Praefectus Vigilum and his staff were tasked with cautioning all tenants or property (nedostaje riječ, vjerojatno owners, iako se možda mislilo i na slaves, op. a.) in the city not to cause fires through their lack of care (aliqua neglegentia)." Usp. du Plessis 2013, 283. Vidi također Petrucci $2012,150$.

${ }^{65}$ U vezi s pitanjem jesu li vigiles za Augusta imali „vojarne“ kao stalno mjesto okupljanja iz kojih bi djelovali, kao u kasnijim stoljećima, ili su bili raspoređeni „per hospitia“, s uputom na daljnju literaturu vidi Sablayrolles 1996, 27.

${ }^{66}$ Sablayrolles tekst tumači u smislu prava prefekta da uđe u domove ljudi bez odobrenja, no ne samo u slučaju nastalog požara veći radi provjere imaju li sve predviđeno za prevenciju. Usp. Sablayrolles 1996, 105 isl. 
D. 1, 15, 3, 1 (Paulus libro singulari de officio praefecti vigilum) Cognoscit praefectus vigilum de incendiariis effractoribus furibus raptoribus receptatoribus, nisi si qua tam atrox tamque famosa persona sit, ut praefecto urbi remittatur. Et quia plerumque incendia culpa fiunt inhabitantium, aut fustibus castigat eos qui neglegentius ignem habuerunt, aut severa interlocutione comminatus fustium castigationem remittit. ${ }^{67}$

Iz navedenog dijela Paulova komentara vidljivo je da je u okviru Augustove organizacije službi koje su bile zadužene za osiguranje uredna odvijanja života u gradu primarna odgovornost što se tiče ispitivanja i odlučivanja u slučajevima narušavanja reda i mira bila na praefectus vigilum. On je ispitivao, istraživao, ne samo slučajeve podmetača požara već i provalnika, lopova, razbojnika te njihovih pomagača ${ }^{68}$, no kako bi se moglo zaključiti prema drugoj rečenici, ipak se njegova nadležnost $u$ prvom redu ostvarivala na području kažnjavanja izazivača požara ${ }^{69}$, iako pritom u ograničenom opsegu. ${ }^{70}$ Razlog je bila činjenica da je o ozbiljnijim slučajevima, u slučaju opasnih osoba ili ozloglašenih pojedinaca, trebao odlučiti praefectus Urbi, a što potvrđuje i Ulpijan u D. 1, 15, 4 u svom komentaru o ovlastima praefectus Urbi iz kojega je dio upravo preuzet u ovaj titul. ${ }^{11}$

${ }_{67}$ D. 1, 15, 3, 1: „Praefectus vigilum ispituje u slučajevima protiv podmetača požara, provalnika, kradljivaca, pljačkaša (razbojnika) te osoba koje im pomognu pri skrivanju (pruže im utočište), osim ako je riječ o tako opasnoj ili zloglasnoj (infamnoj) osobi, koju treba predati praefectus urbi (upravitelju grada). I zbog toga što su požari često nastali krivnjom stanara, može ili kazniti šibanjem one koji su nemarno držali vatru ili bi ih umjesto šibanja ozbiljno ukorio." Usp. Lenel (I) 1889, 1144.

${ }_{68}$ O sudskim ovlastima praefectus vigilum vidi MacCormack 1972, 389 i sl.; Robinson 1977, 381 i sl.; Sablayrolles 1996, 103 i sl.; Jaramaz-Reskušić 2003, 215; Sitek 2007; Kołodko 2012, 204 i sl. Također vidi Saumagne 1962, 337 i sl.

${ }^{6}$ Uz to treba dodati da je praefectus vigilum prema D. 1, 15, 3, 5 bio nadležan i za istrage protiv čuvara odjeće u kupalištima (capsarii), a prema D. 19, 2, 56 i D. 20, 2, 9 koji su uzeti iz iste knjige (Paulus libro singulari de officio praefecti vigilum) rješavao je i u sporovima najmodavaca i najmoprimaca stanova i skladišta, iako i tu više u svojstvu policijske vlasti nego samoga suda. Za navedene te daljnje slučajeve, primjerice, vidi Kaser 1996, 465, bilj. 46; Kołodko 2012, 205, 210. Također, a u vezi sa širenjem primjene kognicijskog postupka, prema CIL VI, 266 praefectus vigilum 226. g. riješio je i u slučaju dužnih pensiones udruženja fullones. Usp. de Robertis 1982, 791 i sl.; Rüfner 2016, 262.

70 Navedeno, međutim, ne treba tumačiti na način da su njegove ovlasti općenito bile uske. Naprotiv, one su s vremenom bile sve važnije i šire. Niz poznatih pravnika obavljao je tu službu, a Domicijan je uveo i subpraefectus vigilum, očito zbog povećana opsega posla. Vidi Sablayrolles 1996, 104 i sl.

${ }_{71}$ D. 1, 15, 4 (Ulpianus libro singulari de officio praefecti Urbi): „Imperatores Severus et Antoninus lunio Rufino praefecto vigilum ita rescripserunt: „insularios et eos, qui neglegenter ignes apud se habuerint, potes fustibus vel flagellis caedi iubere: eos autem, qui dolo fecisse incendium convincentur, ad Fabium Cilonem praefectum urbi amicum nostrum remittes: fugitivos conquirere eosque dominis reddere debes"." (Carevi Sever i Antonin su tako otpisali Juniju Rufinu, praefectus vigilum: „Možeš narediti da budu išibani ili bičevani oni stanari koji su nemarno držali vatre. One za koje bude utvrđeno da su namjerno uzrokovali požar prepusti našem prijatelju gradskom prefektu Fabiju Cilonu. Odbjegle robove moraš uhvatiti i vratiti ih gospodarima."). Usp. Lenel (II) 1889, 960.

Također, u vezi s tim da praefectus vigilum ne može odlučiti u postupcima u kojima prijeti smrtna kazna vidi jedinu konstituciju Justinijanova Kodeksa unutar titula De officio praefecti vigilum s kraja 4. st., C. 1, 43,1 (Imperatores Valentinianus, Theodosius, Arcadius): „Praefecti vigilum huius urbis nihil de capitalibus causis 
Štoviše, Ulpijan, navodeći edikt Septimija Severa i Karakale, upućuje na to da bi svako podmetanje požara koje bi povlačilo kaznenopravnu odgovornost, tj. dolozno ili namjerno podmetanje, pripadalo pod nadležnost praefectus Urbi, dok je praefectus vigilum bio taj koji je trebao kazniti šibanjem (udaranjem štapom) ili bičevanjem one koji su nemarno držali vatre. ${ }^{72}$ Bi li u potonjem slučaju bila riječ samo o kažnjavanju zbog nepažnje pri održavanju plamena, primjerice u smislu da je kod nekoga bio uočen otvoren plamen na koji nitko ne bi pazio jer su stanari ili robovi zaspali ili se udaljili na duže vrijeme, ili o požarima koji su nastali iz takvih požara, iz same dikcije Ulpijanova fragmenta nije jasno. Druga rečenica Paulova teksta u kojoj se spominje da su požari često bili uzrokovani nepažnjom stanara te bi trebalo išibati one koji su nemarno držali vatre, a s obzirom na istodobnost radnji, nije puno preciznija iako bismo je prije tumačili da bi se odnosila na nastale požare. S jedne strane, mogla bi se naglasiti kauzalna veza između dviju rečenica u smislu da su požari nastali zbog nemarnog održavanja vatre, no s druge strane, moglo bi se inzistirati i na razlici ignis i incendium. ${ }^{73}$ Međutim, u povodu činjenice da bi u slučaju požara uzrokovanog nepažnjom postojala u prvom redu deliktna odgovornost prema actio legis Aquiliae ${ }^{74}$, a posebno u vezi s D. 47, 9, 9 (Gaius 4 ad legem duodecim tabularum)75 i tekstovima Collatio sadržanima u 12. titulu De incendariiis ${ }^{76}$, te prema riječima D. 48, 19, 28, 12 (Callistratus libro sexto de cognitionibus) $)^{77}$, trebalo bi ipak uzeti da je nadležnost postojala u slučaju

sua auctoritate statuere debent, sed si quid huiusmodi evenerit, culmini tuae potestatis referre, ut de memoratis causis celsiore sententia iudicetur." (Praefecti vigilum ovoga grada ne smiju po vlastitom ovlaštenju odlučivati o kapitalnim slučajevima (u kojima prijeti smrtna kazna ili capitis deminutio), već ako bi se što takvo dogodilo, trebaju to uputiti tvojoj vrhovnoj vlasti da bi o navedenim slučajevima bila donesena odluka po višem tijelu."

72 Usp. MacCormack 1972, 390; Sablayrolles 1996, 105 i sl.; Kołodko 2012, 206 i sl.

73 Navedena veza izričitije je istaknuta u tekstovima o odgovornosti za požar kod damnum iniuria datum i kod locatio conductio, pri čemu se u okviru navedenih titula jasno navodi incendium kao posljedica i temelj odgovornosti za štetu. Bi li ovdje ignis bilo navedeno upravo radi otklona od kaznenopravno relevantnog incendium nije jasno, no primjerice u Coll. 12 incendium se jednako koristi i kod namjerno i slučajno nastalog požara.

74 O tužbi vidi, primjerice, Eisner, Horvat 1948, 456 i sl.; Kaser 1971, 609 i sl.; Zimmermann 1992, 953 i sl.; Hausmaninger 1996.

75 Taj tekst nalazi se u titulu De incendio ruina naufragio rate nave expugnata, u kojem je riječ o kažnjavanju slučajeva iskorištavanja okolnosti požara i sličnih radi pribavljanja protupravne koristi, a uzima se da prenosi odredbu Zakonika 12 ploča, Tab. 8.10, prema kojoj je namjerno uzrokovanje požara kažnjavano smrću na lomači, a nenamjerno ili slučajno uzrokovanje lakše ili samo obvezom naknade štete, što su u romanistici pratile kritike glede izvornosti podjele, odnosno da je riječ o kasnijem razvoju tumačenja odredbe. S uputom na daljnju literaturu, opširnije vidi u: Daube 1936, 254 i sl.; MacCormack 1972, 382 i sl.; MacCormack 1981, 116 i sl.; Cursi 2012, 300 i sl.

76 S uputom na daljnju literaturu, vidi Minieri 2011, 252 i sl.; du Plessis 2013, 282.

77 Tekst D. 48, 19, 28, 12 nalazi se u okviru titula o kaznama te se u njemu navodi da će podmetači požara biti kažnjeni capite, no akoje do požara došlo slučajno, odnosno požarje uzrokovao štetu susjedima zbog nepažnje onoga koji je palio vatru, odgovarat će se civiliter, tj. civilnom ili građanskopravnom tužbom, ili će biti umjereno kažnjeni (... Nam fortuita incendia, si, cum vitari possent, per neglegentiam eo- 
tako nastalog požara. Naznaka sadržana u D. 1, 15, 3, 1 te u reskriptu prenesenom u D. $1,15,4$, "eos, qui neglegenter ignes apud se habuerint", mogla bi se upravo objasniti time da je s obzirom na zahtjev postojanja dolus malus kod kaznenopravne odgovornosti za požar ${ }^{78}$ bilo potrebno posebno istaknuti da je dopušteno ukoriti ili tjelesno kazniti i one koji su nepažnjom uzrokovali požar. ${ }^{79}$ Uostalom, i samo određenje kada je požar uzrokovan namjerno ili nepažnjom češće bi bilo rezultat prefektova ispitivanja stvari pa je stoga logično da bi se i navedena kazna šibanja ili usmeno upozorenje odnosili na slučaj kada bi prefekt ustanovio da je požar nastupio zbog nemarnosti. Prije bi se moglo staviti pod upitnik njegovo kažnjavanje same činjenice nemarnog držanja vatre ako nije nastao požar ${ }^{80}$, a posebno s obzirom na D. 1, 15, 3, 3.

Ne ulazeći u pitanja svih oblika kaznenopravne regulacije uzrokovanja požara te evoluciju sudbenosti extra ordinem pred praefectus vigilum, iz navedenih tekstova titula de officio praefecti vigilum može se zaključiti da je na općoj razini postojala određena podudarnost ovlasti triumviri capitales i praefectus vigilum. Konkretnije, što se tiče uređenja organizacijskih elemenata protupožarne zaštite kako je ona koncipirana u razdoblju principata, a usporedbom s literaturnim izvorima o djelovanju triumviri i quinqueviri, može se reći da izvori upućuju na sadržajni kontinuitet, odnosno odmjenu službi u vezi s opsegom njihovih djelatnosti, pri čemu se ne može identificirati niša u kojoj bi postojali eventualni nocturni kao prethodnici vigiles.

\section{ZAKLJUČAK}

Na temelju razmatranja $u$ radu u vezi s pravnom regulacijom organizacije protupožarne zaštite može se uočiti da su u Rimu već relativno rano, u skladu sa širenjem grada i povećanjem broja magistratura, postojali posebni organi čiji je zadatak bio noćni nadzor radi ranog sprečavanja i borbe protiv požara. Na temelju Paulova uvoda u D. 1, 15, 1 te samo dvaju navoda Livija i Valerija Maksima koji spominju triumviri nocturni te suprotno impostiranog Liv. XXXIX, 14, 10 prema kojem bi za noćne ophodnje bili nadležni triumviri capitales, u vezi s kojima postoji veći broj dokaza u literatur-

rum, apud quos orta sunt, damno vicinis fuerunt, civiliter exercentur (ut qui iactura adfectus est, damni disceptet) vel modice vindicaretur.).

${ }^{78}$ Vidi titul D. 48, 8 (Ad legem Corneliam de siccariis et veneficis), posebno D. 48, 8, 1 (Marcianus 14 institutionum) i D. 48, 8, 10 (Ulpianus 18 ad edictum). Također vidi D. 48, 6, 5 pr. (Marcianus 14 institutionum) u vezi s podmetanjem požara i radi pobune ili izazivanja nemira. Usp. MacCormack 1972, 387 i sl.; Amielańczyk 2000, 6 i sl. U vezi s D. 48, 8, 10 (Ulpianus 18 ad edictum) i izrazom quasi incendiarius usp. Minieri 2011, 251 i sl.

${ }_{79}$ O kažnjavanju i u slučaju izostanka namjere kao elementu postupka extra ordinem usp. Pugliese 1982, 761; Jaramaz Reskušić 2003, 321; Kołodko 2012, 206 i sl.

so U tom smislu Kołodko govori o fizičkom kažnjavanju ako je požar nastao, no „if the potential careless offender had not actually caused a fire yet, perhaps it was enough for the prefect of the vigiles to issue a severe reprimand". Usp. Kołodko 2012, 207. Također, u izvorima nema temelja za postojanje formalnoga kaznenog djela (držanja opasne vatre) u smislu kako navodi Amielańczyk 2000, 15. 
nim, pravnim i epigrafskim izvorima, u romanistici postoje suprotstavljena mišljenja o postojanju dvije ili samo jedne magistrature. Općenito bismo se priklonili stavu da u posljednja dva stoljeća republike nisu postojale dvije službe, međutim, oslanjajući se pritom i na prijašnja istraživanja, u prvom redu teze i rezultate Sablayrollesa i Cascionea, $u$ vezi s organizacijom protupožarne borbe smatramo da je vjerojatno da su tresviri nocturni postojali prije, tijekom 4. i 3. stoljeća prije Krista. Također, držimo mogućim da su nakon ustanovljenja triumviri capitales kao redovite, u skupštini izabrane magistrature ovlasti triumviri nocturni apsorbirane od triumviri capitales, i to primarno kroz ustanovljenje, ili njihovu zamjenu, ili proširenje s quinqueviri uls cis Tiberim. Međutim, kao što je vidljivo iz zapisa za Augustovo doba, sama činjenica da su nove magistrature osnivane kao pomoćne starima dovodila je do preklapanja ovlasti te je dolazilo do konkurencije, katkad pozitivne, katkad negativne, koja je mogla otežavati samu borbu protiv požara.

Radi osiguranja efikasne i jedinstvene organizacije vatrogasne postrojbe August je tako osnovao sedam kohorti vigiles na čijem je čelu bio praefectus vigilum s određenim policijskim i sudskim ovlastima, u prvom redu u vezi sa svim onim nedopuštenim radnjama i ponašanjima s kojima su se vigiles susretali u noćnim ophodnjama. Do vremena Paula i Ulpijana, koji su svaki ostavili liber singularis de officio praefecti vigilum iz kojih su preuzeti fragmenti u odgovarajućem titulu Digesta, praefectus vigilum stekao je relativno šire sudske ovlasti što se tiče kažnjavanja podmetača požara. Uz to, iz Paulova se komentara može steći dojam da je prefekt morao svake večeri ići u ophodnje i opominjati ljude koji bi držali otvoren plamen koji bi mogao ugroziti građevine te provjeravati da imaju dovoljno vode za gašenje eventualnih požara, međutim u vezi s time mogu se izraziti određene sumnje. Ako bi se povukla paralela s pretpostavljenim odnosom triumviri i quinqueviri, čini nam se prije da bi praefectus vigilum bio u određenom stanju pripravnosti te obavljao povremeni nadzor nad djelovanjem vigiles predvođenih tribunima i centurionima, dok bi oni bili ti koji su imali stvarni nadzor te vodili stvarnu borbu protiv požara.

\section{LITERATURA}

1. Amielańczyk K. (2000). Dolus malus - animus occidendi: The Problem of Cuilt in the lex Cornelia de sicariis et veneficis, u: Zablocka, M. et al. (ur.), Au-delà des frontières: Mélanges de droit romain offerts à Witold Wołodkiewicz, I. Liber, Varsovie, str. 1-15.

2. Badot, P. (1973). A propos de la conspiration de M. Egnatius Rufus. Latomus, 32 (3), str. 606-615.

3. Briscoe, J. (2019). Valerius Maximus, Facta et dicta memorabilia, Book8- Text, Introduction, and Commentary. De Gruyter, Berlin-Boston.

4. Canter, H. V. (1932). Conflagrations in Ancient Rome. The Classical Journal, 27 (4), str. 270288. 
5. Capogrossi Colognesi, L.; Gabba, E. (ur.), (2006). Cli statuti municipali. IUSS Press, Pavia.

6. Cascione, C. (1999). Tresviri capitales. Storia di una magistratura minore. Editoriale scientifica, Napoli.

7. Cascione, C. (2010). Sul nome (e il numero) dei «tresviri capitales». A ritroso da Borges a Insus, cavaliere trionfante. Index. Quaderni camerti di studi romanistici, 38, str. 21-35.

8. Cursi, M. F. (2012). Roman Delicts and the Construction of Fault, u: McGinn, T. A. J. (ur.), Obligations in Roman Law. The University of Michigan Press, Ann Arbor, str. 296-319.

9. Daube, D. (1936). On the Third Chapter of the lex Aquilia. Law Quarterly Review, 52, str. 253268 (= Daube, D. (1991). Collected studies in Roman Law, I. Vittorio Klostermann, Frankfurt am Main, str. 3-18).

10. Daugherty, G. N. (1992). The Cohortes Vigilum and the Great Fire of 64 AD. The Classical Journal, 87 (3), str. 229-240.

11. De Robertis, F. M. (1982). Lis fullonum, u: Temporini, H. (ur.), Aufstieg und Niedergang der römischen Welt, Il.14. De Gruyter, Berlin, New York, str. 791-815.

12. Dell'Oro, A. (1960). I Libri de officio nella giurisprudenza romana. Giuffrè, Milano.

13. Divković, M. (1900/2006). Latinsko-hrvatski rječnik, Dunja, Bjelovar.

14. Domaszewski, A. von (1892). Nocturni, Rheinisches Museum für Philologie, 47, str. 159160.

15. Du Plessis, P. (2013). Notes on a fire, u: Sturm, F.; Phili, T.; Jochen, O. (ur.), Liber Amicorum Guido Tsuno. Vico, Frankfurt am Main, str. 277-284.

16. Eck, W. (2015). Die Amtsträger: Instrumente in den Händen des Princeps und Begrenzung der Autokratie. Traditioneller Cursus und kaiserliche Ernennung, u: Ferrary, J.-L.; Scheid, J. (ur.), II princeps romano: autocrate o magistrato? Fattori giuridici e fattori sociali del potere imperiale da Augusto a Commodo. IUSS Press, Pavia, str. 613-677.

17. Eisner, B.; Horvat, M. (1948). Rimsko pravo. Nakladni zavod Hrvatske, Zagreb.

18. Enßlin, W. (1954). Praefectus, u: Ziegler, K. (ur.), Paulys Realencyclopädie der classischen Altertumswissenschaft, 22. Bd. Alfred Druckenmüller Verlag, Stuttgart, str. 1257-1347.

19. Ernout, A.; Meillet, A. (1959/2001). Dictionnaire étymologique de la lingue latine. Klincksieck, Paris.

20. Fercia, R. (2008). La responsabilità per fatto di ausiliari nel diritto romano. CEDAM, Padova.

21. Fuhrmann, C. J. (2016). Police Functions and Public Order, u: du Plessis, P. J.; Ando, C.; Tuori, K. (ur.), The Oxford Handbook of Roman Law and Society. Oxford University Press, Oxford, str. 297-309.

22. Guarino, A. (1962). Le notti del «praefectus vigilum», Labeo, 8, str. 348-350.

23. Hausmaninger, H. (1996). Das Schadenersatzrecht der lex Aquilia, 5. Aufl. Manzsche Verlagsund Universitätsbuchhandlung, Wien.

24. Horvat, M. (1943). Rimska pravna poviest. Knjižara Zlatko Streitenberger, Zagreb.

25. Houston, G. W. (1976). Notes on Some Documents Pertaining to Flavian Administrative Personnel. Zeitschrift für Papyrologie und Epigraphik, 20, str. 25-34. 
26. Jaramaz-Reskušić, I. (2003). Kaznenopravni sustav u antičkom Rimu. Hrvatsko udruženje za kaznene znanosti i praksu, Ministarstvo unutarnjih poslova Republike Hrvatske, Zagreb.

27. Johnson, A. C.; Robinson Coleman-Norton, P.; Card Bourne, F. (1961/2009). Ancient Roman Statutes. University of Texas Press, Austin.

28. Karlović, T. (2021). Ignis, incendium, fortuitus casus - D. 19, 2, 9, 3 i opasnost štete od požara kod locatio fundi. Pravni vjesnik, 37 (3-4), (u postupku objave).

29. Karlović, T. (2006). The Legal Status of Municipium Andautonia, u: Thür, G.; Lučić, Z. (ur.), „Imperium und Provinzen" (Zentrale und Regionen). Pravni fakultet Univerziteta u Sarajevu, Sarajevo, str. 51-74.

30. Kaser, M. (1971). Das römische Privatrecht, I, Das altrömische, das vorklassische und klassische Recht, 2. Aufl. Beck'sche Verlagsbuchhandlung, München.

31. Kaser, M. (1996). Das römische Zivilprozessrecht. C. H. Beck, München.

32. Kleinfeller, G. (1918). Incendium, u: Paulys Realencyclopädie der classischen Altertumswissenschaft, IX, 2 (Halbband 18). Mezler, Stuttgart, str. 1244-1245.

33. Kołodko, P. (2012). The Powers and Significance of the Prefect of the 'Vigiles' ('praefectus vigilum') in Ancient Rome. Zeszyty Prawnicze, 12 (4), str. 199-214.

34. Kunkel, W. (1925). Diligentia. Zeitschrift der Savigny-Stiftung für Rechtsgeschichte. Romanistische Abteilung, 45, str. 266-351.

35. Kunkel, W. (1962). Untersuchungen zur Entwicklung des römischen Kriminalverfahrens in vorsullanischer Zeit. Verlag der Bayerischen Akademie der Wissenschaften, München.

36. Kunkel, W.; Wittmann, R. (1995). Staatsordnung und Staatspraxis der Römischen Republik, Abs. 2. Die Magistratur. C. H. Beck, München.

37. La Rosa, F. (1957). Note sui «tresviri capitales. Labeo, 3, str. 231-245.

38. Lange, L. (1856). Römische Alterthümer l, 1. ed. Weidmannsche Buchhandlung, Berlin.

39. Lenel, O. (1918). Textkritische Miszellen. Zeitschrift der Savigny-Stiftung für Rechtsgeschichte. Romanistische Abteilung, 39, str. 119-171.

40. Lenel, O. (1889). Palingenesia luris Civilis I i II. Tauchnitz, Leipzig. (repr. Vico, Frankfurt am Main, 2006.).

41. Licandro, O. (1999). In magistratu damnari. Ricerche sulla responsibilita dei magistrati romani duarnte lesercizio delle fenzioni. Ciappichelli Editore, Torino.

42. Lintott, A. (1999). Violence in Republican Rome. Oxford University Press, Oxford.

43. MacCormack, G. (1972). Criminal Liability for Fire in Early and Classical Roman Law. Index. Quaderni camerti di studi romanistici, 3, str. 382-396.

44. MacCormack, G. (1981). Fault and Causation in Early Roman Law: An Anthropological Perspective. Revue internationale des droits de l'antiquité, 28, str. 97-126.

45. Maschi, C. A. (1976). La conclusione della giurisprudenza classica all'età dei Severi. Iulius Paulus, u: Temporini, H. (ur.), Aufstieg und Niedergang der römischen Welt, 11.15. De Gruyter, Berlin, New York, str. 667-707. 
46. Minieri, L. (2004). Normative Antincendio in Diritto Romano Tardo Classico e Postclassico. IVS ANTIQVVM, Drevnee pravo, 1 (13), str. 83-90.

47. Minieri, L. (2011). Sul quasi incendiarius. Revue internationale des droits de l'antiquité, 58, str. 250-273.

48. Mommsen, T. (1874). Römisches Staatsrecht, II, 1. Verlag S. Hirzel, Leipzig.

49. Nippel, W. (1995). Public Order in Ancient Rome. Cambridge University Press, Cambridge.

50. Nörr, D. (1976). Pomponius oder „Zum Ceschichtsverständnis der römischen Juristen“, u: Temporini, H. (ur.), Aufstieg und Niedergang der römischen Welt, II.15. De Gruyter, Berlin, New York, str. 498-604.

51. Pailler, J.-M. (1985). Rome aux cinq régions? Mélanges de l'école française de Rome, 97 (2), str. 785-797.

52. Petrak, M. (2006). Kritika teorije o samopomoći kao prvobitnom obliku pravne zaštite (SelbsthiIfetheorie). Zbornik Pravnog fakulteta u Zagrebu, 56 (5), str. 1249-1287.

53. Petrucci, A. (2012). Corso di diritto pubblico Romano. Giappichelli Editore, Torino.

54. Pugliese, G. (1982.). Linee generali dell'evoluzione del diritto penale pubblico durante il principato, u: Temporini, H. (ur.), Aufstieg und Niedergang der römischen Welt, II.14. De Gruyter, Berlin, New York, str. 720-789.

55. Rainbird, J. S. (1976). The Vigiles of Rome. Durham University, Durham. Dostupno na http:// etheses.dur.ac.uk/7455/ (5. 12. 2020.).

56. Robinson, O. F. (1994). Ancient Rome: City Planning and Administration. Routledge, London, New York.

57. Robinson, O. F. (1977). Fire prevention at Rome. Revue internationale des droits de l'antiquite, 24 , str. 377-388.

58. Romac, A. (1975). Stambene prilike u starom Rimu. Codišnjak Pravnog fakulteta u Sarajevu, 23, str. 141-174.

59. Romac, A. (1989). Paulo, Sentencije. Latina et Graeca, Zagreb.

60. Romano, L. (2016). Ordinamenti oschi e diritto pubblico romano: «tresviri capitales» nella tavola bantina? Index. Quaderni camerti di studi romanistici, 44, str. 91-99.

61. Roselaar, S. T. (2016). Local Administration, u: du Plessis, P. J.; Ando, C.; Tuori, K. (ur.), The Oxford Handbook of Roman Law and Society. Oxford University Press, Oxford, str. 124-136.

62. Rüfner, T. (2016.). Imperial cognitio Process, u: du Plessis, P. J.; Ando, C.; Tuori, K. (ur.), The Oxford Handbook of Roman Law and Society. Oxford University Press, Oxford, str. 257-269.

63. Sablayrolles, R. (1996). Libertinus miles. Les cohortes de vigiles. École Française de Rome, Rome.

64. Saumagne, C. (1962). Les Incendiaires de Rome (ann. 64 p. C.) et les lois pénales des Romains (Tacite, Annales, XV, 44). Revue Historique, 227 (2), str. 337-360.

65. Sitek, B. (2007). Criminal Liability of 'incendiarii' in Ancient Rome, Diritto e Storia, 6. Dostupno na http://www.dirittoestoria.it/6/Rassegne/Sitek-Incendiarii-ancient-Roman-Law.htm (25. 1. 2021.). 
66. Strasburger, B. (1939). Triumviri, u: Kroll, W.; Mittelhaus, K. (ur.), Paulys Realencyclopädie der classischen Altertumswissenschaft, 7 A (13er Halbband). J. B. Metzlersche Verlagsbuchhndlung, Stuttgart, str. 511-521.

67. Von Beseler, G. (1930). Opora. Universitätsverlag von R. Noske, Leipzig.

68. Wolf, J. G. (2011.). Die Lex Irnitana : ein roemisches Stadtrecht aus Spanien. Lateinisch und deutsch. WBG, Darmstadt.

69. Zimmermann, R. (1992). The Law of Obligations: Roman Foundations of the Civilian Tradition. Oxford University Press, Cape Town, Johannesburg.

\section{Summary}

\section{SOME CONSIDERATIONS ON THE ORGANIZATION OF FIRE PROTECTION SERVICES IN ROMAN LAW}

The article elaborates on the general features of fire protection services in Rome through two stages of development, as provided by texts preserved within the Digest entitled De officio praefecti vigilum, and the pertaining legal issues concerning the organization of these services. After the introductory part, the author discusses the issue of the identity of triumviri nocturni and of their separate existence within the structures of magistracies in the Republican period. He goes on to present the Augustan creation of the service of vigiles, and the considerations on the duties of praefectus vigilum as their commander and the person entrusted with legal authority to deal with the fire fighting and prevention activities. In the concluding remarks the reassessment of key issues on the legal organization of fire prevention services according to the Roman legal sources is provided.

Key words: fire, fire protection services, firefighting, triumviri nocturni, praefectus vigilum, vigiles. 